Sharing of injection equipment by 212 drug abusers

\begin{tabular}{lrc}
\hline & $\begin{array}{c}\text { No (\%) using injection } \\
\text { equipment after } \\
\text { someone else }\end{array}$ & $\begin{array}{c}\text { No (\%) allowing } \\
\text { someone else to use } \\
\text { injection equipment } \\
\text { after themselves }\end{array}$ \\
\hline Never & $35(16)$ & $61(29)$ \\
Previously but no longer & $158(75)$ & $87(41)$ \\
Yes but only with someone well known & $11(5)$ & $40(19)$ \\
Yes with anyone & $8(4)$ & $24(11)$ \\
\hline Total & $212(100)$ & $212(100)$ \\
\hline
\end{tabular}

discrepancy in numbers between the two groups suggests that those in the second group have been sharing with drug abusers not receiving treatment and thus a policy of providing clean syringes should logically extend to those not attending treatment units, although this might encourage more drug abusers to start injecting.

Because sharing of syringes is associated with a feeling of community among drug users and not only with a shortage of needles, ${ }^{4}$ it is unlikely to cease if syringes become more easily available. In addition, a drug user may forget his or her own syringe or be tempted to have an unplanned fix. It is not surprising, therefore, that infection with the AIDS virus among drug users in Italy has risen sharply despite the free availability of syringes. ${ }^{5}$

Fear of AIDS, the educational measures adopted so far, and treatment at specialist units already seem to have reduced injecting and sharing among clinic attenders, and this must be taken into account in any future assessment of the effect of policy initiatives. The question to be addressed will be the extent to which sharing may be reduced further by providing free syringes.

1 Friedland GH, Harris C, Butkus-Small C, et al. Intravenous drug abusers and the acquired immune deficiency syndrome (AIDS). Arch Intern Med 1985;145:1413-7.

2 Andreyev HJN. Selling syringes to drug addicts. Lancet 1985;ii:1192-3.

3 Scottish Home and Health Department. HIV infection in Scotland. Edinburgh: Scottish Home and Health Department, 1986.

4 Black JL, Dolan MP, DeFord HA, et al. Sharing of needles among users of intravenous drugs. $N$ Englf Med 1986;314:446-7.

5 Moss AR. AIDS and intravenous drug use: the real heterosexual epidemic. Br Med f 1987;294: $389-90$.

(Accepted 10 fuly 1987)

St George's Hospital Medical School, London SW17 ORE

A H GHODSE, PHD, FRCPSYCH, professor, department of psychiatry

G TREGENZA, MB, CHB, assistant psychiatrist, section of psychiatry of addictive behaviour

M LI, MD, WHO research fellow, section of psychiatry of addictive behaviour

Correspondence to: Professor A H Ghodse, Department of Psychiatry, St George's Hospital Medical School, Cranmer Terrace, London SW17 0RE.

\section{Arthropathy in a patient with cystic fibrosis taking ciprofloxacin}

Ciprofloxacin is a broad spectrum antibiotic available as tablets that has good activity against Pseudomonas aeruginosa. Though used for recurrent chest infection in adults with cystic fibrosis, ${ }^{1}$ it is not recommended for under 18 year olds, mainly because of arthropathy with cartilage erosion seen in young animals given the drug or related compounds (G Schlüter, in proceedings of first international ciprofloxacin workshop, Leverkusen (Bayer), 6-8 November 1985, pp 61-70). We report the case of a 16 year old girl with cystic fibrosis and advanced lung disease who received ciprofloxacin on a named patient basis. She developed arthropathy of both knees after three weeks, which resolved completely within two weeks of stopping the drug.

\section{Case report}

This girl had cystic fibrosis diagnosed on the basis of sweat tests at 15 month and 7 years, a positive family history (a brother had died of the disease at 13), and typical clinical findings. In January 1986, at the age of 16 , she had an exacerbation of respiratory symptoms. Sputum yielded a heavy growth of $P s$ aeruginos $a$, and after an unsatisfactory response to two weeks of tobramycin and azlocillin she was prescribed oral ciprofloxacin $750 \mathrm{mg}$ twice daily (body weight $33 \mathrm{~kg}$ ). Oral flucloxacillin, stanozolol $2.5 \mathrm{mg}$ daily, gentamicin and carbenicillin by inhalation, and standard vitamin and pancreatic supplements were continued as before. On review at 18 days sputum characteristics had improved, she had gained $2 \mathrm{~kg}$, and the white cell count had returned to normal. Serum urea, electrolyte, and glucose concentrations, liver function, prothrombin time, and results of urine analysis, obtained before ciprofloxacin and repeated at 18 days, were normal.

At 20 days she felt less well, reporting pain in both knees, worse on standing, and discomfort in one wrist. Examination showed warmth and swelling of both knees with effusion in one and a small popliteal cyst in the other; movement was full but painful. No other joint abnormalities were found and there was no rash There was no improvement after two days' bed rest, and ciprofloxacin was stopped. She was not given anti-inflammatory agents. Inflammation began to decrease after a further two days, and by two weeks all abnormalities had resolved.

Results of investigations five days after stopping ciprofloxacin were: sedimentation rate $50 \mathrm{~mm}$ in first hour; positive rheumatoid factor titre $(1 / 64)$ and negative viral screens; serum negative for antinuclear factor, mitochondrial antibody, smooth muscle antibody, and autoantibodies to extractable nuclear antigens; evidence of circulating immune complexes shown by monoclonal rheumatoid factor binding assay $(65 \%$; normal $<15 \%)$; and serum total haemolytic complement normal. All values were similar four months later, when serum urate concentration was also normal and she was negative for HLA-B27. Serum IgG concentration was $35 \cdot 4 \mathrm{~g} / \mathrm{l}$ (normal 6-15), IgA $9 \cdot 46 \mathrm{~g} / \mathrm{l}(1 \cdot 0-4 \cdot 8)$, and $\mathrm{IgM} 1 \cdot 85 \mathrm{~g} / \mathrm{l}$ $(0 \cdot 5-2 \cdot 5)$.

Radiographs of the knees during the arthropathy were normal and, in common with radiographs of the hands and feet, four months later showed no periostitis or erosion of articular cartilage.

\section{Comment}

Arthropathy occurs in 7-8\% of adolescents and adults with cystic fibrosis, usually affecting knees and ankles. ${ }^{2}$ Causes are cystic fibrosis arthropathy, hypertrophic pulmonary osteoarthropathy, and miscellaneous. The transient synovitis of cystic fibrosis arthropathy is usually recurrent over weeks or months. Our patient had no arthropathy before ciprofloxacin and none developed during the ensuing 18 months. There was no radiological evidence of hypertrophic pulmonary osteoarthropathy, though we accept that, rarely, clinical features may exist before $x$ ray changes. ${ }^{2}$

Among other causes of arthropathy in cystic fibrosis hyperuricaemia, pancreatitis, and viral infections either were not suggested clinically or were excluded by investigation. Rheumatoid factor is found in many chronic pulmonary infections, including cystic fibrosis. ${ }^{23}$ Our patient's serum was not tested before the arthropathy. Subsequently she remained positive for rheumatoid factor but did not fulfil diagnostic criteria for rheumatoid arthritis. ${ }^{4}$ Circulating immune complexes were detected but these are commonly found in chronic pulmonary infections, ${ }^{3}$ being attributed to bacterial antigens rather than autoantigens.

The evidence suggests that our patient's arthropathy was due to ciprofloxacin rather than another cause. Unlike the arthropathy seen in young animals given quinolone compounds (though in higher dosage; G Schlüter, cited above) there was no erosion of joint cartilage. The manufacturer reports that between May 1983 and December 1985, 75 patients aged under 18 received 83 courses of ciprofloxacin for many diagnoses. Of these patients, 49 with cystic fibrosis received 56 courses. Two girls aged 14 and 10 with cystic fibrosis developed arthralgia: knees were affected in both patients and ankles in one after treatment for one and three months, respectively. Both girls recovered fully soon after stopping ciprofloxacin (Bayer, personal communication).

We thank Mr N Amos, of the department of rheumatology, for helpful discussions.

1 Hodson ME, Roberts CM, Rutland RJA, Smith MJ, Batten JC. Ciprofloxacin compared with conventional intravenous treatment for Pseudomonas aenuginosa infection in adults with cystic fibrosis. Lancet 1987; i:235-7.

2 Phillips BM, David TJ. Pathogenesis and management of arthroplasty in cystic fibrosis. $\mathcal{J} R$ So Med 1986;79(suppl 12):44-60.

3 Bartfeld H. Distribution of rheumatoid factor activity in non-rheumatoid states. Ann NY Acad Sc 1969;168:30-40.

4 American Rheumatism Association. Diagnostic criteria for rheumatoid arthritis. 1958 Revision. Ann Rheum Dis 1959;18:49-51.

(Accepted 10 fuly 1987)

University Hospital of Wales, Heath Park, Cardiff CF4 4XW

M ALFAHAM, MRCP, research fellow in cystic fibrosis, department of child health

MARY E HOLT, MD, MRCP, senior registrar, department of rheumatology

MARY C GOODCHILD, MD, DCH, associate specialist in cystic fibrosis, department of child health

Correspondence to: Dr Alfaham. 